\title{
News from a small island - first record of a freshwater shrimp (Decapoda, Atyidae, Caridina) from Peleng, Banggai Islands, Indonesia
}

\author{
Kristina von Rintelen ${ }^{\mathrm{a} *}$, Andreas Karge ${ }^{\mathrm{b}}$ and Werner Klotz ${ }^{\mathrm{c}}$ \\ ${ }^{a}$ Museum für Naturkunde, Humboldt-Universität zu Berlin, Berlin, Germany; \\ ${ }^{b}$ Magdeburgerstrasse 42, Schoenebeck, Germany; ${ }^{c}$ Wiesenweg 1, Rum, Austria
}

(Received 5 November 2007; final version received 4 June 2008)

\begin{abstract}
The Indonesian island Sulawesi is well known for its fascinating fauna. Among the atyid and palaemonid freshwater shrimps described from Sulawesi are also a number of endemic species. In contrast, freshwater shrimps have never been reported from the nearby and smaller Peleng Island. Here we describe Caridina thomasi sp. nov. as a first record of an atyid freshwater shrimp from Peleng and compare it with atyids from Sulawesi and other localities. The new species is probably endemic to the island and shows some characters never described in the genus Caridina before. However, a molecular phylogeny of atyid shrimps from the Indo-West Pacific based on mitochondrial DNA (16S) places C. thomasi within a clade of typical species of Caridina. We tentatively assign the new species to the genus Caridina and discuss the possibility of future changes in the classification of species in this genus.
\end{abstract}

Keywords: oceanic island; new species; atyid shrimp; systematics; mitochondrial DNA

\section{Introduction}

The fauna of oceanic islands, particularly in the tropics, is often unique. The Indonesian island of Sulawesi hosts a high number of endemic and non-endemic species, among these three genera of freshwater shrimps (Crustacea, Decapoda, Atyidae) with currently 33 species (see Table 1). Twenty species from two genera (mainly Caridina H. Milne Edwards, 1837) are endemic to Sulawesi. In contrast to non-endemic taxa, these produce a small number of large eggs indicative of an abbreviated or direct larval development (Benzie 1982; Hayashi and Hamano 1984; Shy et al. 2001). However, atyid freshwater shrimps have never been reported from Peleng, one of the Banggai Islands close to the east coast of Luwuk Peninsula, Central Sulawesi (Figure 1), although both islands are close to each other. The second freshwater shrimp group (Crustacea, Decapoda, Palaemonidae) known from Sulawesi (Holthuis 1950; Chace and Bruce 1993; Dudgeon 2006; Wowor and Ng 2007), albeit lacking endemic taxa on the island (Daisy Wowor personal communication 2007), has likewise never been reported from Sulawesi's small neighbour. As a first record for freshwater shrimps we here describe Caridina thomasi sp. nov. from a karstic river in the mountains of Peleng Island and compare it with C. typus H. Milne Edwards, 1837, a morphologically similar species from Sulawesi, and other atyid shrimps. We use a molecular phylogeny based on the mitochondrial gene $16 \mathrm{~S}$ to discuss the position of the new species within the Atyidae.

*Corresponding author. Email: Kristina.Rintelen@museum.hu-berlin.de 
Table 1. Species of atyid freshwater shrimps reported from the Indonesian island of Sulawesi.

Taxon

Atyopsis Chace, 1983

Atyopsis spinipes (Newport, 1847)

Caridina H. Milne Edwards, 1837

C. acutirostris Schenkel, 1902

C. appendiculata Jalihal and Shenoy, 1998

C. brachydactyla De Man, 1908

C. brevicarpalis De Man, 1892

C. buehleri Roux, 1934

C. celebensis De Man, 1892

C. ensifera Schenkel, 1902

C. gracilipes De Man, 1892

C. gracilirostris De Man, 1892

C. lanceolata Woltereck, 1937a

C. lingkonae Woltereck, 1937a

C. loehae Woltereck, 1937a

C. linduensis Roux, 1937

C. longidigita Cai and Wowor, 2007

C. longifrons Cai and $\mathrm{Ng}, 2007$

C. masapi Woltereck, $1937 \mathrm{a}$

C. neglecta Cai and $\mathrm{Ng}, 2007$

C. opaensis Roux, 1904

C. pareparensis De Man, 1892

C. parvidentata Roux, 1904

C. sarasinorum Schenkel, 1902

C. spec. (formerly known as C. multidentata Stimpson, 1860)

C. spinata Woltereck, $1937 \mathrm{a}$

C. spongicola Zitzler and Cai, 2006

C. tenuirostris Woltereck, $1937 \mathrm{a}$

C. towutensis Woltereck, $1937 \mathrm{a}$

C. typus $\mathrm{H}$. Milne Edwards, 1837

C. villadolidi Blanco, 1939

C. weberi De Man, 1892

C. wyckii (Hickson, 1888)
State of endemism

non-endemic

endemic

non-endemic

non-endemic

non-endemic

non-endemic

non-endemic

endemic

non-endemic

non-endemic

endemic

endemic

endemic

endemic

endemic

endemic

endemic

non-endemic

endemic

endemic

endemic

endemic

endemic

endemic

endemic

endemic

endemic

non-endemic

non-endemic

non-endemic

non-endemic

Marosina Cai and $\mathrm{Ng}, 2005$

M. brevirostris Cai and $\mathrm{Ng}, 2005$

endemic

M. longirostris Cai and $\mathrm{Ng}, 2005$

endemic

\section{Material and methods}

\section{Species collection and morphology}

Specimens were caught by hand net and preserved in $75-95 \%$ ethanol during a fieldtrip to Peleng Island in 2005 (C. thomasi) and to Sulawesi in 2003 and 2005 (C. typus), respectively (Figure 1; see below for details). Two species with a small number of large eggs, Caridina lanceolata and Caridina spec. chosen as representatives of Sulawesi's endemic shrimp fauna were collected from two distant localities in 2003. Additional material of C. typus was collected from Bali and Halmahera, Indonesia, 


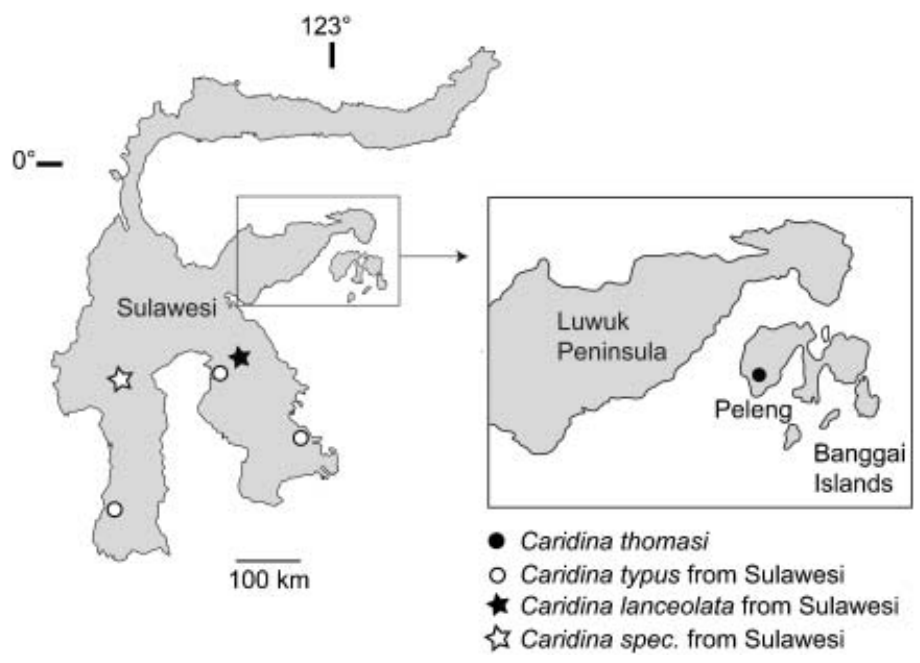

Figure 1. Peleng, the largest of the Banggai Islands, close to the east coast of Luwuk Peninsula, Sulawesi. Collecting site of Caridina thomasi, new species, from Peleng and additional collecting sites of other species of Caridina from Sulawesi.

in 2005. Caridina gracilirostris de Man, 1892 (ZMB 29459) used for the molecular phylogeny was collected by A. Karge 2007 in Bentota, Sri Lanka.

For the descriptive part of the study we used 62 specimens of $C$. thomasi and 12 specimens of $C$. typus as comparative material. Morphometric measurements were taken using a stereomicroscope with an ocular micrometer. All measurements and qualitative characters of $C$. thomasi are from 62 specimens, unless otherwise indicated. Drawings of dissected specimens (see Figures 2, 3) were made with a drawing tube mounted on a stereomicroscope or a light microscope for fragile body appendages or from microphotographs. In addition, five paratype specimens (ZMB 29413) were studied by scanning electron microscopy (SEM). Specimens fixed in $95 \%$ ethanol were dehydrated in $100 \%$ ethanol for 30 minutes and afterwards were critical point dried with a BAL-TEC CPD 030, mounted on aluminium specimen stubs with standard adhesive pads and coated with gold-palladium using a Polaron SC7 640 Sputter Coater. SEM pictures were taken on a LEO 1450VP SEM (software: $32 \mathrm{V02.03)}$ ) at $10 \mathrm{kV}$.

\section{Molecular phylogeny}

For the molecular phylogeny we used 22 published sequences as well as four sequences of C. typus, one of C. gracilirostris, one of C. spec. from Sulawesi, one of C. lanceolata from Sulawesi and three of $C$. thomasi (see Table 2). Paratya australiensis Kemp, 1917 and Atyaephyra desmarestii (Millet, 1832) were chosen as outgroup taxa.

DNA was extracted exclusively from abdominal tissue. For the molecular phylogeny approximately 560 base pairs (bp) of the large ribosomal subunit (16S) were amplified and sequenced on an ABI 3130 capillary DNA sequencer using atyidspecific primers 16S-F-Car, 16S-R-Car and 16S-R-Car1 (von Rintelen et al. 2007).

The orthologous DNA sequences obtained were aligned, using default settings, using CLUSTAL W, v.1.81 (Thompson et al. 1994). Blocks of poorly aligned sites among the original alignment of $518 \mathrm{bp}$ were identified using GBLOCKS version 0.91b 

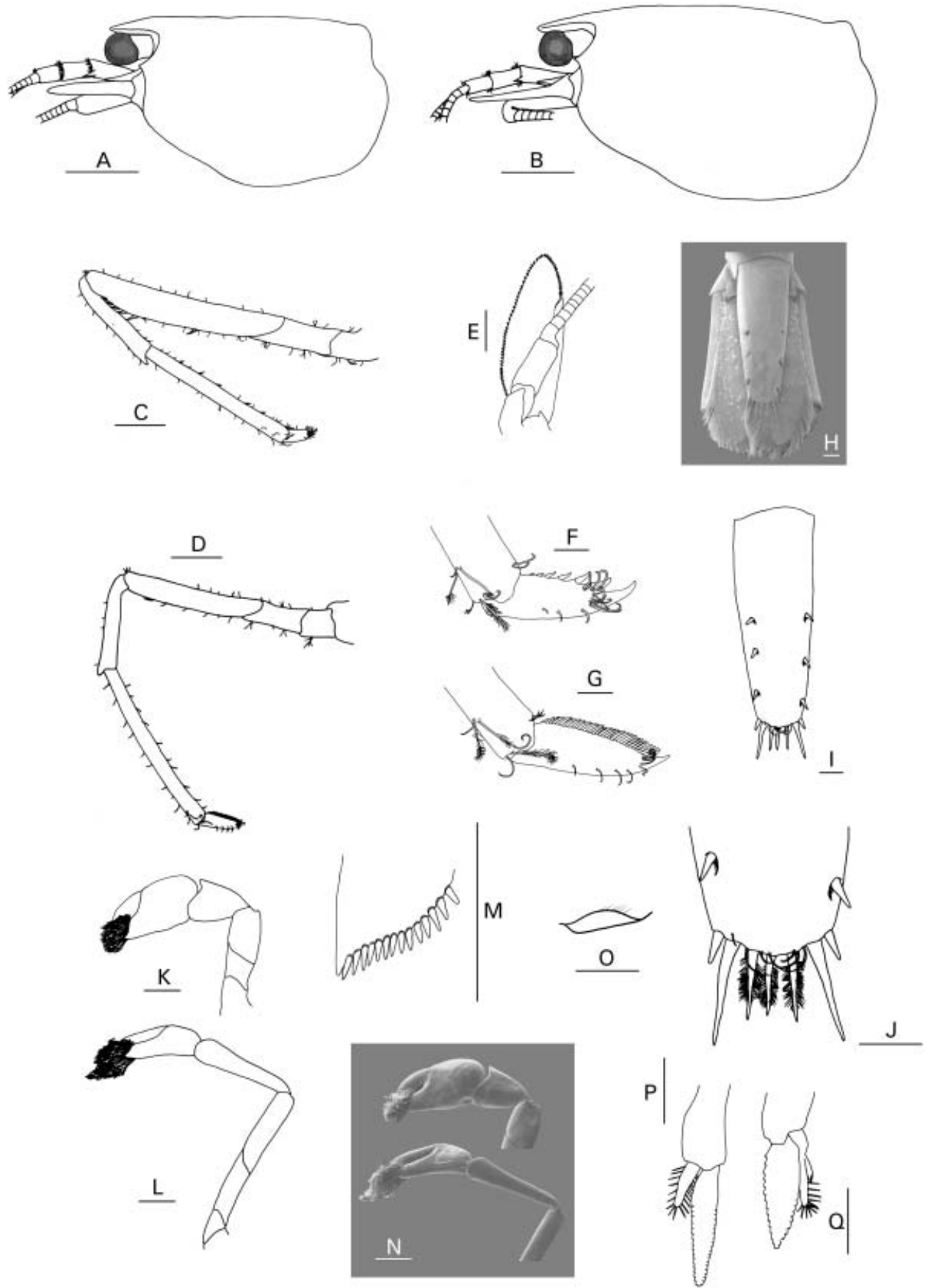

Figure 2. Caridina thomasi, new species. (A) Cephalothorax and cephalic appendages, paratype male [carapace length (CL) $4.1 \mathrm{~mm}$; ZMB 29413]; (B) cephalothorax and cephalic appendages, paratype female (CL $4.3 \mathrm{~mm}$; ZMB 29413); (C) third pereiopod; (D) fifth pereiopod; (E) scaphocerite; (F) dactylus of third pereiopod; $(\mathrm{G})$ dactylus of fifth pereiopod; (H) scanning electron micrograph of telson and uropods; (I) telson; (J) distal end of telson; (K) 
(Castresana 2000) (parameters $=$ minimum number of sequences for conserved position, 17; minimum number of sequences for flanking position, 27; maximum number of contiguous non-conserved positions, 8; minimum length of block, 10; allowed gap positions: with half). GBLOCKS identified 50 positions (10\%) as being problematic and so these were not included in later analyses because of their suspect nature.

Phylogenetic analyses were performed using maximum likelihood (ML) with PAUP 4.0b10 (Swofford 2002) under the appropriate model of sequence evolution $(\mathrm{GTR}+\mathrm{I}+\Gamma)$ selected using Modeltest 3.7 (Posada and Crandall 1998) by likelihood ratio tests. The ML analysis used the heuristic search option with 10 random sequence addition replicates. The dataset was also subjected to a bootstrap analysis with random sequence addition and 100 bootstrap replicates.

\title{
Species and sequence deposition
}

Type specimens are deposited in the Division of Zoology, Research Centre for Biology, Indonesian Institute of Sciences (MZB; formerly Museum Zoologicum Bogoriense), Bogor, Indonesia and the Museum für Naturkunde (ZMB; formerly Zoologisches Museum Berlin), Humboldt-Universität zu Berlin, Germany. The abbreviation CL is used for carapace length, measured from the postorbital to the posterior margin of the carapace. The length of the antennular peduncle was measured from the orbital margin to the distodorsal margin of the third segment.

Sequences have been deposited in GenBank; see Table 2 for accession numbers.

\section{Results}

\section{Taxonomy}

\author{
Family ATYIDAE De Haan
}

Caridina H. Milne Edwards, 1837

Caridina thomasi sp. nov.

(Figures 2, 3)

\section{Material examined}

Holotype. Female, CL $4.7 \mathrm{~mm}$ (MZB Cru 1682), Indonesia, Central Sulawesi, Banggai Islands, Peleng, west peninsula, east of Alani, river with lake-like extension, $\left(01^{\circ} 28.315^{\prime} \mathrm{S} 122^{\circ} 52.473^{\prime} \mathrm{E}\right.$; collected by K. and T. von Rintelen, 25 September 2005$)$.

Paratypes. Sixteen females, CL 3.0-5.3 mm (MZB Cru 1683), same data as holotype; 14 males, CL 3.4 $4.5 \mathrm{~mm}$ (MZB Cru 1683), same data as holotype. 15 females, CL 2.8-4.9 mm (ZMB 29413), same data as holotype; three ovigerous females, CL 4.6$5.1 \mathrm{~mm}$ (ZMB 29413), same data as holotype; 13 males, CL 3.4-4.3 mm (ZMB 29413), same data as holotype.

first pereiopod; (L) second pereiopod; (M) uropodal diaeresis; (N). scanning electron micrograph of chela and carpus of first and second pereiopods; (O) preanal carina, paratype male (CL $3.8 \mathrm{~mm}$; MZB Cru 1683); (P) endopod of male first pleopod (ZMB 29413); (Q) appendix masculina of male second pleopod. Scale bars: A, B, P, Q=1.0 mm; C-E, K$\mathrm{O}=0.5 \mathrm{~mm} ; \mathrm{H}-\mathrm{J}=2.2 \mathrm{~mm} ; \mathrm{F}, \mathrm{G}=0.1 \mathrm{~mm}$. 
Table 2. Sequence provenience and accession numbers used for the $16 \mathrm{~S}$ molecular phylogeny.

\begin{tabular}{|c|c|c|c|c|}
\hline Taxon & & Sample site & $\begin{array}{c}\text { GenBank }^{\mathrm{a}} \\
\text { EMBL }^{\mathrm{b}} \\
\text { accession number }\end{array}$ & $\begin{array}{l}\text { Source (museum } \\
\text { accession numbers for } \\
\text { ZMB) }\end{array}$ \\
\hline Atyaephyra & desmarestii & Italy & DQ681285 & Page et al. 2007b \\
\hline Atyoida & bisulcata & Hawaii & DQ681278 ${ }^{\mathrm{a}}$ & Page et al. 2007b \\
\hline Atyopsis & moluccensis & Indo-Pacific region & DQ681281 ${ }^{\mathrm{a}}$ & Page et al. 2007b \\
\hline Australatya & striolata & Australia & AY795035 & Page et al. 2005b \\
\hline \multirow[t]{22}{*}{ Caridina } & africana & South Africa & DQ478483 ${ }^{\mathrm{a}}$ & Page et al. 2007a \\
\hline & cantonensis & Hong Kong & DQ478487 & Page et al. 2007a \\
\hline & celebensis & Malaysia & AY708127 & Bossuyt et al. 2004 \\
\hline & confusa & Australia & DQ478495 & Page et al. 2007a \\
\hline & gracilirostris & Sri Lanka & EU873516 ${ }^{\mathrm{a}}$ & This study (ZMB 29459) \\
\hline & lanceolata & Indonesia, Sulawesi & EU873517 & This study (ZMB 29081) \\
\hline & longirostris & Australia & DQ478507 & Page et al. 2007a \\
\hline & serratirostris & Australia & DQ478515 & Page et al. 2007a \\
\hline & spec. & Indonesia, Sulawesi & EU873518 & This study (ZMB 29256) \\
\hline & steineri & Madagascar & DQ681274 ${ }^{\mathrm{a}}$ & Page et al. 2007b \\
\hline & trifasciata & Hong Kong & DQ478557 & Page et al. 2007a \\
\hline & typus & Indonesia, Sulawesi & $\mathrm{AM} 747633^{\mathrm{b}}$ & $\begin{array}{l}\text { von Rintelen et al. } 2007 \\
\quad(\text { ZMB 29092) }\end{array}$ \\
\hline & & & EU873519 & This study (ZMB 29019) \\
\hline & & & EU $873520^{\mathrm{a}}$ & This study (ZMB 29206) \\
\hline & & Indonesia, Bali & EU873521 ${ }^{\mathrm{a}}$ & This study (ZMB 29344) \\
\hline & & $\begin{array}{l}\text { Indonesia, } \\
\text { Halmahera }\end{array}$ & EU873522 ${ }^{\mathrm{a}}$ & This study (ZMB 29409) \\
\hline & thomasi & Indonesia, Peleng & EU873523 ${ }^{\mathrm{a}}$ & This study (ZMB 29413) \\
\hline & & & EU873524 & This study (ZMB 29413) \\
\hline & & & EU873525 & This study (ZMB 29413) \\
\hline & weberi & Micror & DQ478564 ${ }^{\mathrm{a}}$ & Page et al. 2007a \\
\hline & wyckii & Indonesia, Sulawesi & DQ478494 ${ }^{\mathrm{a}}$ & $\begin{array}{l}\text { Page et al. 2007a (ZMB } \\
\text { 29274) }\end{array}$ \\
\hline & zebra & Australia & AY $661486^{\mathrm{a}}$ & Page et al. 2005a \\
\hline Caridinides & wilkinsi & Australia & DQ681273 ${ }^{\mathrm{a}}$ & Page et al. 2007b \\
\hline Lancaris & singhalensis & Sri Lanka & AY708123 & $\begin{array}{l}\text { Bossuyt et al. } 2004 \text { (as } C \text {. } \\
\quad \text { singhalensis) }\end{array}$ \\
\hline Neocaridina & denticulata & Japan & DQ681268 ${ }^{\mathrm{a}}$ & Page et al. 2007b \\
\hline Paratya & australiensis & Australia & DQ478566 ${ }^{\mathrm{a}}$ & Page et al. 2007a \\
\hline Parisia & unguis & Australia & DQ681288 ${ }^{\mathrm{a}}$ & Page et al. $2007 \mathrm{~b}$ \\
\hline Pycnisia & raptor & Australia & DQ681271 ${ }^{\mathrm{a}}$ & Page et al. 2007b \\
\hline
\end{tabular}

\section{Comparative material examined}

Caridina typus H. Milne Edwards, 1837. One ovigerous female, CL $8.7 \mathrm{~mm}$ (ZMB 29092), with over 100 eggs, egg size $0.40-0.45 \times 0.24-0.29 \mathrm{~mm}(n=20$, eggs without eyes), Indonesia, South Sulawesi, Maros karst, Bantimurung, above the waterfall, $05^{\circ} 0.96^{\prime} \mathrm{S} 119^{\circ} 40.92^{\prime} \mathrm{E}$; collected by K. and T. von Rintelen, 12 October 2003 . One ovigerous female, CL $8.2 \mathrm{~mm}$ (ZMB 29019), with over 100 eggs, egg size 0.38$0.43 \times 0.24-0.26 \mathrm{~mm}(n=10$, eggs without eyes), Indonesia, Southeast Sulawesi, 

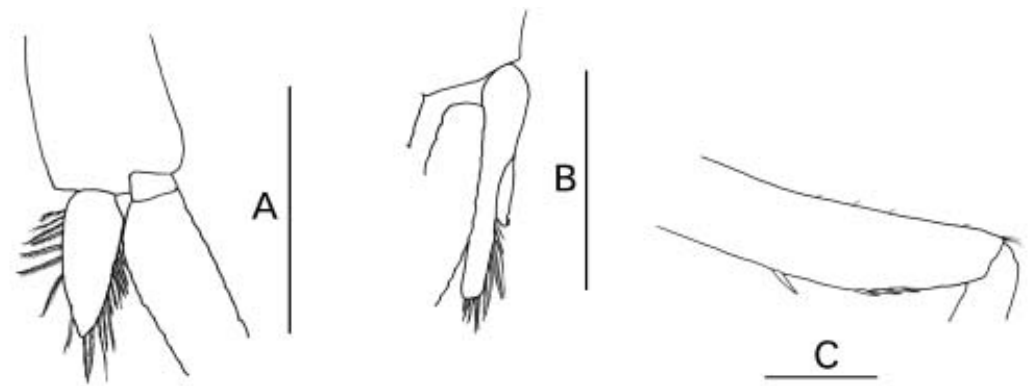

$\mathrm{C}$
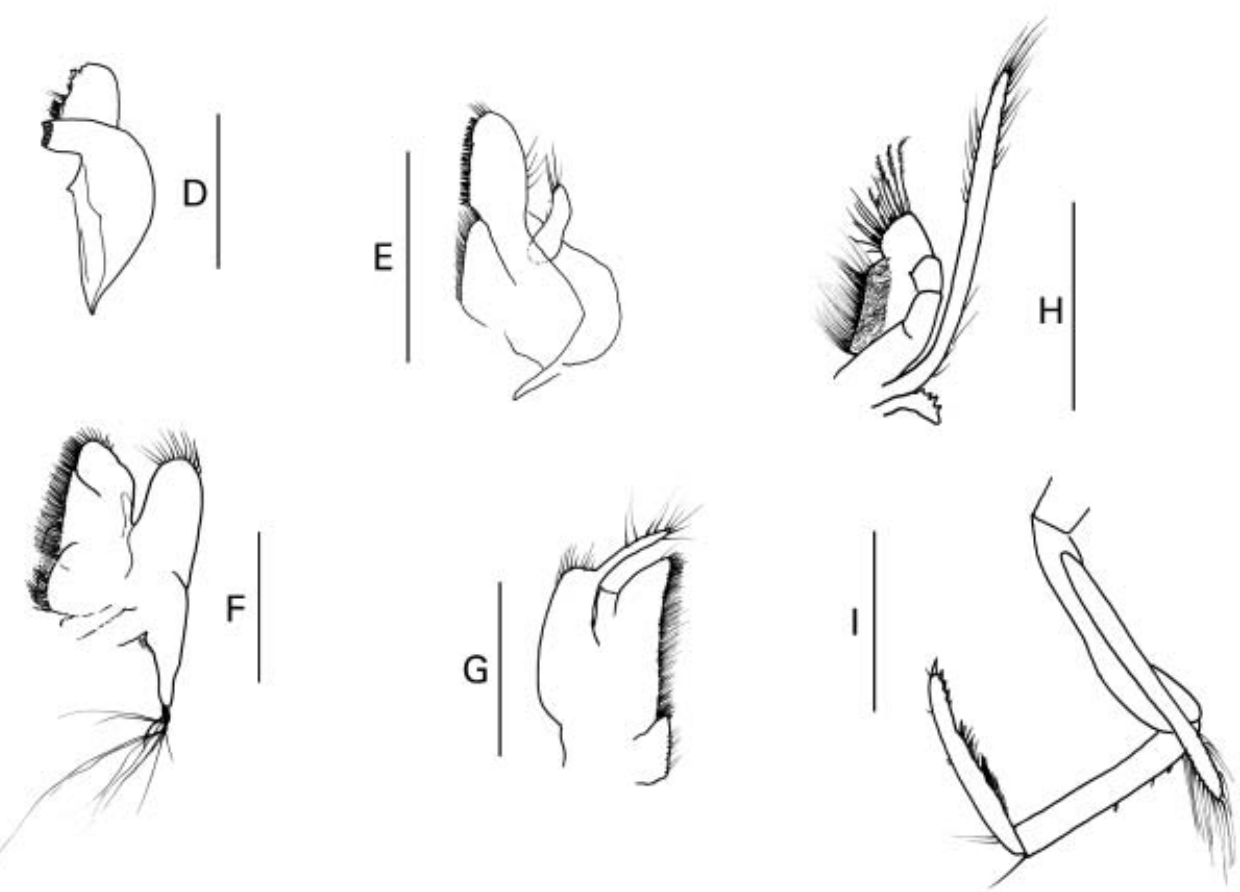

Figure 3. Caridina thomasi, new species, paratype male (carapace length $3.8 \mathrm{~mm}$; MZB Cru 1683). (A) endopod of male second pleopod; (B) appendix masculina on male second pleopod; (C) arrangement of spines on merus of third pereiopod; (D) mandible; (E) maxillula; (F) maxilla; (G) first maxilliped; (H) second maxilliped; (I) third maxilliped. Scale bars: A$\mathrm{I}=1.0 \mathrm{~mm}$.

stream north of Abola, road Tinobu-Kendari, 034․ $495^{\prime} \mathrm{S} 122^{\circ} 15.298^{\prime} \mathrm{E}$; collected by M. Glaubrecht, 1 June 2005. One ovigerous female, CL $5.9 \mathrm{~mm}$ (ZMB 29206), with over 100 eggs, egg size $0.41-0.44 \times 0.25-0.26 \mathrm{~mm}(n=10$, eggs with eyes), Indonesia, Southeast Sulawesi, river at road Malili-Tolala, $02^{\circ} 52.5^{\prime} \mathrm{S} 121^{\circ} 4.75^{\prime} \mathrm{E}$; collected by K. and T. von Rintelen, 12 September 2003. Six females, CL 3.8-7.0 mm (ZMB 29344), Indonesia, Bali, South Bali, stream north of Antap, tributary of Yehotan River, $08^{\circ} 30.746^{\prime} \mathrm{S} 115^{\circ} 1.37^{\prime} \mathrm{E}$; collected by M. Glaubrecht and K. and T. von Rintelen; one male CL $4.2 \mathrm{~mm}$ (ZMB 29344), same data as females. One ovigerous female, CL $7.4 \mathrm{~mm}$ (ZMB 29409), with over 100 eggs, egg size 0.40$0.42 \times 0.25-0.28 \mathrm{~mm}(n=10$, eggs without eyes), Indonesia, Moluccas, Halmahera, river at road Sidangoli-Tobelo, $00^{\circ} 58.879^{\prime} \mathrm{N} 127^{\circ} 37.42^{\prime} \mathrm{E}$; collected by $\mathrm{K}$. von 
Rintelen, 19 September 2005; one female CL $7.7 \mathrm{~mm}$ (ZMB 29409), same data as ovigerous female.

\section{Description}

Cephalothorax and cephalic appendages. Carapace length 2.8-5.3 mm (median $4.0 \mathrm{~mm}$ ). Rostrum straight and short (Figure 2A,B), not reaching to basal segment of antennular peduncle and not reaching beyond length of eyes, $0.2-0.3$ (median 0.2 ) times as long as carapace, completely unarmed, only one male with one dorsal tooth at half length of rostrum (MZB Cru 1683). Inferior orbital angle fused with indistinct antennal spine. Pterygostomian angle broadly rounded. Eyes well developed with cornea globular, anterior end reaching two-thirds of basal segment of antennular peduncle. Antennular peduncle $0.5-0.7$ (median 0.6) times as long as carapace $(n=58)$, second segment 1.1-2.0 times length of third segment $(n=31)$, third segment $0.2-0.5$ times length of basal segment $(n=29)$. Stylocerite reaching well beyond halflength of basal segment of antennular peduncle, but not reaching end of it. Scaphocerite (Figure 2E) 2.7-2.9 times as long as wide $(n=5)$.

Abdominal somites, telson and uropods. Sixth abdominal somite 0.4-0.6 (median 0.5) times length of carapace, 1.6-2.1 (median 1.8) times as long as fifth somite, about as long as telson. Telson (Figure 2H-J) 2.5-3.1 (median 2.6) times as long as proximally wide $(n=21)$, distal margin broadly rounded and slightly flattened, without median projection, with three to five pairs of dorsal spinules and one pair of dorsolateral spinules; distal end with four to eight spines, lateral pair distinctly longer than intermediate spines. Preanal carina rounded, lacking a tooth or spine with few setae (Figure 2O). Uropodal diaeresis (Figure 2M) with 13-15 movable spinules $(n=11)$.

Mouthparts and branchiae. Incisor process of mandible ending in irregular teeth, molar process truncated (Figure 3D). Lower lacinia of maxillula broadly rounded, upper lacinia elongate, with numerous distinct teeth on inner margin, palp slender with few simple setae at tip (Figure 3E). Upper endites of maxilla subdivided, palp short, scaphognathite tapering posteriorly, fringed with long, curved setae at posterior margin (Figure 3F). Palp of first maxilliped ending in a broadly triangular projection (Figure $3 \mathrm{G}$ ). Podobranch on second maxilliped reduced to a lamina with few finger-like projections (Figure $3 \mathrm{H}$ ). Third maxilliped with one arthrobranch, ultimate segment as long as or slightly shorter than penultimate segment (Figure 3I). Pleurobranchs present on all pereiopods. First pereiopod without arthrobranch. Well-developed epipods present on third maxilliped and first four pereiopods.

Pereiopods. Chela and carpus of first pereiopod distinctly stouter and broader than chela and carpus of second pereiopod (Figure $2 \mathrm{~K}, \mathrm{~L}$ and $\mathrm{N}$ ); chela of first pereiopod $1.8-2.1$ as long as wide $(n=19), 1.3-2.1$ times length of carpus; tips of fingers rounded, without hooks; dactylus $0.7-2.0$ as long as palm $(n=19)$; carpus $1.4-1.9$ times as long as wide, $0.9-1.3$ times length of merus $(n=16)$. Chela of second pereiopod 2.2-2.8 times as long as wide $(n=6), 0.8-0.9$ times length of carpus; tips of fingers rounded, without hooks, dactylus $1.0-1.8$ times as long as palm $(n=23)$; carpus 3.8-5.4 times as long as wide $(n=18)$, about as long as or slightly longer than 
merus. Third pereiopod slender (Figures 2C, F; 3C), dactylus 2.7-3.4 times as long as wide (terminal spine included, without spines on flexor margin; $n=6$ ), terminating in one large claw with five to seven accessory spines on flexor margin; propodus 8.811.7 times as long as wide, 3.9-4.7 times as long as dactylus; carpus 5.1-5.8 times as long as wide, $0.6-0.7$ times as long as propodus, $0.5-0.6$ times as long as merus; merus 5.4-6.5 times as long as wide, 1.7-2.0 times as long as carpus, bearing four to six (distal three to five densely spaced) strong, movable spines on posterior margin of outer surface. Distal three to five spines remarkably densely spaced. Fifth pereiopod slender (Figure 2D,G), dactylus 3.1-4.3 times as long as wide (terminal spine included, without spines on flexor margin; $n=6$ ), terminating in one large claw with 33-48 spinules on flexor margin; propodus 10.6-13.3 times as long as wide, 3.3-4.6 times length of dactylus, carpus 5.4-6.0 times as long as wide, 0.5-0.6 times as long as propodus, 0.7 times as long as merus; merus 6.0-6.9 times as long as wide, 1.4-1.5 times length of carpus, bearing one or two strong, movable spines on posterior margin of outer surface.

Pleopods. Endopod of male first pleopod (Figures 2P; 3A) elongated, triangular, 2.4 3.4 times as long as proximal width $(n=6), 0.4-0.5$ times as long as exopod, without appendix interna. Appendix masculina on male second pleopod (Figures 2Q; 3B) slender, rod-like, with long spines on inner and distal margin, appendix interna reaching to about two-thirds of appendix masculina.

Reproductive biology. Ovigerous females with 12-20 eggs ( $n=3$ females); egg size $1.10-1.27 \times 0.71-0.88 \mathrm{~mm}(n=45$, eggs without eyes; sex ratio females : males 1.3 ; ratio females : ovigerous females 10.7$)$.

Distribution. Caridina thomasi is only known from Peleng Island.

Habitat. Karstic freshwater river with a lake-like extension at an altitude of approximately $370 \mathrm{~m}$. Mainly rocks in shallow water with little vegetation. Shrimps were found everywhere, but primarily in crevices of rocks along the shore.

Body colouration of living specimens. Body and appendages bright orange, partly red or yellow (K. and T. von Rintelen, personal field observation).

Etymology. Caridina thomasi is dedicated to Thomas von Rintelen, who not only accidentally discovered the new species with the first author while looking for new snail species, but who also greatly supports the Indonesian shrimp project.

\section{Remarks}

So far, $C$. thomasi is the only freshwater shrimp known from Peleng Island. The small number of eggs and their large size $(>1 \mathrm{~mm}, n=12$ to $n=20)$ as well as the typical freshwater habitat suggest a direct larval development indicative of a local endemism on Peleng Island, similar to other endemic species from Sulawesi (e.g. 
Zitzler and Cai 2006; Cai and Wowor 2007). In contrast, the numerous and comparatively small eggs $(<0.5 \mathrm{~mm}, n>100)$ of $C$. typus are characteristic of a prolonged larval development typical for widespread species (e.g. Benzie 1982; Hayashi and Hamano 1984).

With regards to the short, unarmed rostrum $C$. thomasi resembles the ubiquitous species $C$. typus, but both can easily be separated by their reproductive biology (see above), by the denticulation of the rostrum (ventrally unarmed in $C$. thomasi vs. 0 5(2) ventral teeth in C. typus), the rounded tip of the dactylus of the first pereiopod (vs. with a prominent hook in C. typus), the reduced gill formula (see below) and the body size (CL 2.8-5.3 mm, median $4.0 \mathrm{~mm}$, in C. thomasi vs. $5.9-8.7 \mathrm{~mm}$, median $5.2 \mathrm{~mm}$, in C. typus, the largest representative of the genus). Among other species of the genus Caridina with an abbreviated or direct larval development $C$. thomasi resembles $C$. cebuensis based on its original description from Cebu, Philippines (Cai and Shokita 2006), but differs from this species in its broadly rounded pterygostomian angle of the carapace (vs. subrectangular in C. cebuensis), in the shape of the male's first pleopod (elongated triangular, 0.4-0.5 times as long as exopod vs. subrectangular, 0.25 times as long as exopod in C. cebuensis) and the reduced branchiae.

Caridina thomasi can be further distinguished from C. typus, C. cebuensis and likewise from all other currently described species of the genus Caridina by its characteristic densely arranged spines on the merus of the third and fourth pereiopod (vs. not densely arranged in other species).

Conspicuous characteristics of $C$. thomasi are the reduced branchiae that rather resemble members of the genus Lancaris Cai \& Bahir 2005 and have not been described in Caridina so far: the arthrobranch absent on the first pereiopod, the third maxilliped with only one arthrobranch and the podobranch on the second maxilliped reduced to a lamina. However, from the two currently described species of the genus Lancaris, $C$. thomasi differs in the densely arranged distal spines on the merus of the third and fourth pereiopod, the spines on the distal margin of the telson (intermedial plumose setae shorter than lateral pair vs. longer in Lancaris), the uropodal diaeresis (lateral angle about as long as mesial movable spines vs. shorter in Lancaris) and the absence of an appendix interna on the male first pleopod.

\section{Molecular results}

The ML analysis recovered three trees of equal likelihood ( $\ln \mathrm{L}=4125.87390)$, of which the first one is shown here (Figure 4). Differences in tree topology were only found in the branching order of the C. typus sequences, which are almost identical.

The molecular phylogeny places $C$. thomasi within a well-supported clade of typical species of Caridina: C. africana Kingsley 1882, C. longirostris H. Milne Edwards 1837, C. weberi de Man 1892 and C. wyckii (Hickson 1888), including the cave species $C$. steineri Cai 2005 from Madagascar and the genus Caridinides Calman 1926. Despite considerable morphological differences the sister taxon of $C$. thomasi is the ubiquitous species $C$. gracilirostris, a grouping highly supported by ML bootstrap values. The three specimens of $C$. typus from Sulawesi that were also morphologically examined and the two specimens from Halmahera and Bali are not closely related to $C$. thomasi, but appear in a separate clade with $C$. cantonensis Yü 1938 and C. trifasciata Yam \& Cai 2003. The two endemic species 


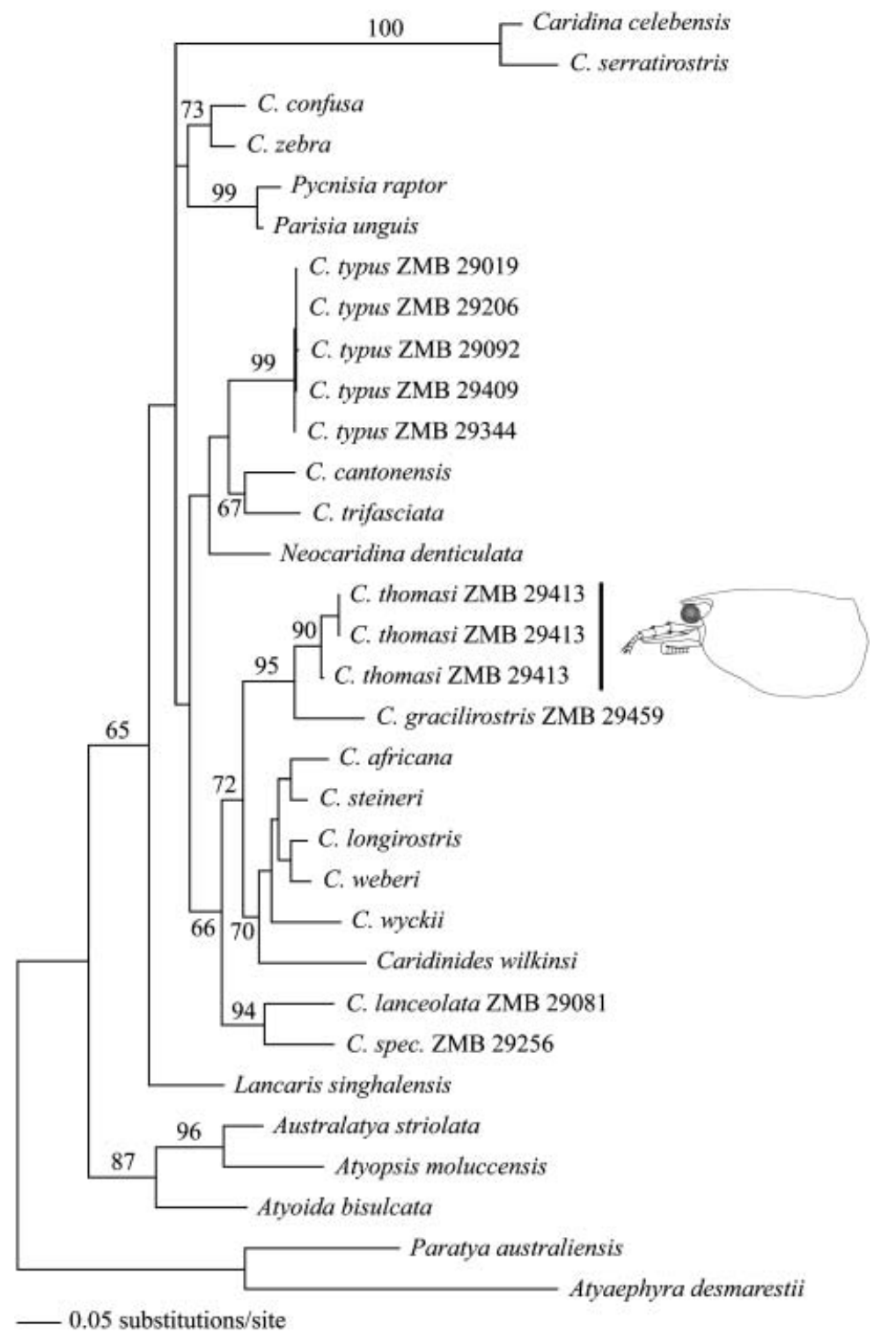

Figure 4. Maximum likelihood phylogram (mitochondrial DNA, 16S) of atyid species from the Indo-West Pacific (maximum likelihood bootstrap values indicated). Position of Caridina thomasi marked with a bold bar.

from Sulawesi, $C$. lanceolata and $C$. spec., are also not closely related to $C$. thomasi. The genus Lancaris is basal to all sequenced species of Caridina and some other atyid genera, such as Pycnisia Bruce 1992, Parisia Holthuis 1956 or Neocaridina Kubo 1938. This topology is not supported by ML bootstrap values, Lancaris and $C$. thomasi are clearly shown to be genetically distinct. For further details and discussion about the majority of already published sequences compare Page et al. (2007a, 2007b). 


\section{Discussion}

The gill formula in atyid shrimps has always been used as a systematic character. In his monograph of the Atyidae, Bouvier delimits his "Série Caridellienne" (Bouvier 1925; p.41) from the "Série Caridinienne" (Bouvier 1925; p.42) based on the absence of an arthrobranch on the first pereiopod. This was later confirmed by Holthuis (1986). He elevated the two groups to the subfamilies Caridellinae and Atyinae. The description of the genus Paracaridina Liang et al. 1999 and the separation of its type species Paracaridina longispina (Guo and He 1992) from the genus Caridina was also based on the missing arthrobranch on the first pereiopod (compare with Guo and de Grave 2004). Recently Cai and Shokita (2006) showed that the closely related species $C$. serratirostris and $C$. celebensis differ by the absence of the same arthrobranch in the latter. However, they discussed it as a secondary loss "rather than as a primarily lacking character to indicate a different phylogenetic lineage" (Cai and Shokita 2006; p. 247). Cai and Bahir (2005) regarded the reduction of the podobranch on the second maxilliped to a lamina instead of a plume as an apomorphy of the genus Lancaris, but later likewise found it in species of the genus Caridina, for example in $C$. ensifera, $C$. sarasinorum and $C$. longidigita from Lake Poso, Sulawesi, Indonesia (Cai and Wowor 2007). This overview shows how variable the gill formula can be in atyid shrimps and that we are still lacking data for a lot of species.

In Caridina the combination of morphology and molecules has already proved to be a powerful tool in taxonomy and species delimitation (e.g. Page et al. 2005b; von Rintelen et al. 2007). Some morphological characters of the new species (only one arthrobranch on the third maxilliped, distal spines on the merus of third and fourth pereiopod densely spaced) may not have been described in Caridina so far, but in combination with the molecular data placing $C$. thomasi in a definite position within a well-supported clade of typical species of Caridina we do not see enough evidence to support the description of a new genus. The topology further supports the morphological delimitation of $C$. thomasi from $C$. typus on one hand and from Lancaris on the other hand.

Based on morphology alone it has already been assumed that species of the genus Caridina did not evolve from a single ancestor (Yixiong Cai personal communication 2005). Page et al. (2007b) mentioned the polyphyly of Caridina from Australia, while Page et al. (2007a) showed the polyphyly of Caridina from the Indo-West Pacific, supporting the general hypothesis of the non-monophyly of the genus. Provided that Lancaris Cai and Bahir 2005 indeed is a distinct genus, Bossuyt et al. (2004) unconsciously also showed the non-monophyly of Caridina from southern India and Sri Lanka, as they had included the two currently known species of Lancaris, $L$. kumariae (de Silva 1990) and L. singhalensis (Ortmann 1894), under their former genus Caridina. A future goal will be the systematic revision of these shrimps with a molecular phylogeny based on several genes in combination with the extensive morphological data that are already available. If we consider C. typus H. Milne Edwards 1837, as the original representative of the genus Caridina, the remaining, non-allied species might be transferred to new genera defined by respective autapomorphies. However, a detailed scenario (who-is-who?) cannot be sketched yet with the present data.

\section{Acknowledgements}

We thank Matthias Glaubrecht (ZMB) for his general support and for collecting Caridina typus from Sulawesi and Bali. Daisy Wowor and Ristiyanti Marwoto (MZB) were of great 
help in Indonesia and LIPI (Indonesian Institute of Sciences) provided research and collecting permits. Thanks to Andreas Wessel and Rebecca Lamers who patiently waited in Luwuk while the rest of the team collected on Peleng Island. We further thank two anonymous referees for their comments on the manuscript.

\section{References}

Benzie JAH. 1982. The complete larval development of Caridina mccullochi Roux, 1926 (Decapoda, Atyidae) reared in the laboratory. J Crust Biol. 2:493-513.

Bossuyt F, Meegaskumbura M, Beenaerts N, Gower DJ, Pethiyagoda R, Roelants K, Mannaert A, Wilkinson M, Bahir MM, Manamendra-Arachchi K, Ng PKL, Schneider CJ, Oommen OV, Milinkovitch MC. 2004. Local endemism within the Western GhatsSri Lanka biodiversity hotspots. Science. 306:479-481.

Bouvier EL. 1925. Recherches sur la morphologie, la geographique des crevettes des la famille des Atyides. Encyclop Entomol. 4:1-370.

Cai Y, Bahir MM. 2005. Lancaris, a new genus of freshwater shrimp from Sri Lanka (Crustacea: Decapoda: Atyidae). Raffles Bull Zool. 12:39-46.

Cai Y, Shokita S. 2006. Report on a collection of freshwater shrimps (Crustacea: Decapoda: Caridea) from the Philippines, with descriptions of four new species. Raffles Bull Zool. 54:245-270.

Cai Y, Wowor D. 2007. Atyid shrimps from Lake Poso, Central Sulawesi, Indonesia with description of a new species (Crustacea: Decapoda: Caridea). Raffles Bull Zool. 55:311-320.

Castresana J. 2000. Selection of conserved blocks from multiple alignments for their use in phylogenetic analysis. Mol Biol Evol. 17:540-552.

Chace FA, Bruce AJ. 1993. The caridean shrimps (Crustacea: Decapoda) of the Albatross Philippine Expedition, 1907-1910, Part 6: Superfamily Palaemonoidea. Smithsonian Contrib Zool. 543:1-23.

Dudgeon D. 2006. The impacts of human disturbance on stream benthic invertebrates and their drift in North Sulawesi, Indonesia. Freshwat Biol. 51:1710-1729.

Guo ZL, de Grave S. 2004. Atyid shrimps of the genus Paracaridina (Crustacea, Decapoda) from Hunan Province, China. Hydrobiologia. 513:197-204.

Hayashi K-I, Hamano T. 1984. The complete larval development of Caridina japonica De Man (Decapoda, Caridea, Atyidae) reared in the laboratory. Zool Sci. 1:571-589.

Holthuis LB. 1950. The Decapoda of the Siboga Expedition, Part X: The Palaemonidae collected by the Siboga and Snellius Expeditions, with remarks on other species, Part I: Subfamily Palaemonidae. Siboga-Expeditie 39a:1-268.

Holthuis LB. 1986. A new genus and species of subterranean shrimp from Western Australia (Crustacea: Decapoda: Atyidae). Zool Medel. 60:103-111.

Page TJ, Baker AM, Cook BD, Hughes JM. 2005a. Historical transoceanic dispersal of a freshwater shrimp: the colonization of the South Pacific by the genus Paratya (Atyidae). J Biogeog. 32:581-593.

Page TJ, Choy SC, Hughes JM. 2005b. The taxonomic feedback loop: symbiosis of morphology and molecules. Biol Lett. 1:139-142.

Page TJ, von Rintelen K, Hughes JM. 2007a. An island in the stream: Australia's place in the cosmopolitan world of Indo-West Pacific freshwater shrimp (Decapoda: Atyidae: Caridina). Mol Phylogen Evol. 43:645-659.

Page TJ, von Rintelen K, Hughes JM. 2007b. Phylogenetic and biogeographic relationships of subterranean and surface genera of Australian Atyidae (Crustacea: Decapoda: Caridea) inferred with mitochondrial DNA. Invert Syst. 21:137-145.

Posada D, Crandall KA. 1998. Modeltest: testing the model of DNA substitution. Bioinformatics. 14:817-818. 
Shy J-Y, Lai HT, Yu H-P. 2001. On the larval development of Caridina formosae (Decapoda, Atyidae) reared in the laboratory. Crustaceana. 74:1159-1168.

Swofford DL. 2002. PAUP*. Phylogenetic analysis using parsimony (*and other methods). Version 4. Sunderland (MA): Sinauer Associates.

Thompson JD, Higgins DG, Gibson TJ. 1994. CLUSTAL W: improving the sensitivity of progressive multiple sequence alignment through sequence weighting, position-specific gap penalties and weight matrix choice. Nucl Acids Res. 22:4673-4680.

von Rintelen K, von Rintelen T, Glaubrecht M. 2007. Molecular phylogeny and diversification of freshwater shrimps (Decapoda, Atyidae, Caridina) from ancient Lake Poso (Sulawesi, Indonesia) - the importance of being colourful. Mol Phylogen Evol. 45:1033-1041.

Wowor D, Ng PKL. 2007. The giant freshwater prawns of the Macrobrachium rosenbergii species group (Crustacea: Decapoda: Caridea: Palaemonidae). Raffles Bull Zool. 55:321-336.

Zitzler K, Cai Y. 2006. Caridina spongicola, new species, a freshwater shrimp (Crustacea: Decapoda: Atyidae) from the ancient Malili lake system of Sulawesi, Indonesia. Raffles Bull Zool. 54:271-276. 